\title{
The concept of the technological sublime in Greek digital art. Views of a new artistic phenomenon in progress
}

\author{
Faye Tzanetoulakou ${ }^{1 *}$, Markella-Elpida Tsichla $^{1}$ and Miltiadis Papanikolaou ${ }^{1}$ \\ ${ }^{1}$ Department of History and Archaeology, Aristotle University of Thessaloniki, Greece
}

\begin{abstract}
The connection of art with science and technology is a constant and inevitable phenomenon that is connected with the character and the existence of organized societies, with the default interactions of people and their achievements and of course has to do with the need of artists to express themselves as fully as possible and with innovative actions. In the history of art, there are many cases of recruitment by artists of scientific and technological achievements in a completely assimilative way, so that the result is considered to be consistent with the evolution of man and his potential. The image, whether static or moving, has effects, sometimes catalytic, so that the artistic data evolve constantly. Contemporary art is in this field today, as it is influenced by digital technology and new media as an additional aspect of postmodern perception. Very quickly, digital art became interactive, diverse, participatory, and multimedia embracing, through digitality, video, photography, sculpture, but also other types and categories of artistic expression, often assisted by music and speech, but also by the internet. In its simplest form it facilitated the dissemination of new art, while it was also a means of art production resulting in a new genre, the "Net Art". Greek artists from the 1980s onwards moved into this artistic landscape, with pioneering Greek artists living abroad and first coming into contact with the Art of the New Media. Entering the 21st century, this kind of art is constantly gaining ground and is one of the main cognitive objects of schools of fine arts and art workshops. The present study seeks to penetrate the aspects of Digital Art in Greece, from its appearance until today.
\end{abstract}

\section{Introduction}

During the first two decades of the 21 st century, Digital Art is constantly gaining ground as one of the main cognitive subjects at schools of fine arts and art workshops. On the other

*Corresponding author: faye.tzanetoulakou@gmail.com 
hand, the international shift to digitalism gives the Art of New Media an intercultural hue and a greater proximity to globalization, which makes the interpretation of Digital Art multidimensional and cross-cultural. The present study seeks to penetrate the aspects of Digital Art in Greece today and name the pioneering artists who practice it in relation to the rediscovery of the notion of the Romantic Sublime, now expressed with different manifestations via the New Media Art, in an attempt to explore the awe-inducing elements hidden under the fast-paced, demystifying rhythms of contemporary life.

As the image of the conceptual era grew more complex, virtuality became an important part of expression, merging space and time, the alternate characteristics of cyberspace, and enriching the senses with new experiences. Very quickly, digital art became interactive, diverse, participatory and multimedia embracing, through digitality, video, photography, the internet. [1]

The present study seeks to attempt an original research, penetrating the aspects of Digital Art within a country of solid classical cultural tradition such as Greece, focusing on its treatment of the topic of the New Romantic Sublime, from its appearance on the fin de siècle until its ubiquitous presence during the first decades of the 21 st century, to the key exhibitions and events that have institutionalized Digital Art in the Greek artistic realm. The topic is especially important during the COVID19 pandemic when artists have to present their works in a virtual environment and at the same time have more time to begin a quest of experiencing long-lost Romantic preoccupations with seeking the Self's identity, within a world brimming of fragmented, unheroic images and lack of true Romantic ideals.

\section{Methodology}

The methodology of the work uses philosophical and social approaches for qualitative data analysis. For the philosophers of the Sublime, the way of interpretation comes through a deep understanding of the meaning of the Sublime, while for sociologists of interaction, through the understanding of how the Sublime is affecting and is interpreted by the audience. Interpretations of man's new relationship with himself and the world are studied and analyzed on the basis of Simon Morley's iconic volume "The Sublime”, published by the Whitechapel Gallery, an inclusive compilation of documents by several authors on the topic's contemporary manifestations, but also through the emerging technology and the changing meaning of the human entity, in the Anthropocene Era [2].

The presentation will focus on the advent of the New Media technologies on the creative industries of art-making. We will research why the attention of presenting art is shifted towards utilizing the new technological advances in re-writing the image, aiming to explore how Avant is the very recent tech-oriented art Garde in Greece, as a small in scale but integral part of the international digital art scene, utilizing the idea of the archetypical Romantic Sublime and how it has been reinstated to form the Contemporary Technological Sublime in the context of novel digital technologies applied to the visual arts, often borrowing elements from tech-friendly niches such as video games or phone applications.

Taking as a starting point the notion of the $19^{\text {th }}$ century Romantic Sublime, of the enchantment infused within the tantalizing combination of awe and fear mainly caused by powerful natural phenomena, we apply it to our age of disenchantment caused by an unprecedented economic crisis, combined with an immense influx of information, merging the higher emotion with the banal, and more often than not, the horrific, which this time is caused by the effect human beings have on nature and each other, during the age of social indifference and Climate Change. However, both $19^{\text {th }}$ and $21^{\text {st }}$ century types of the Sublime refer to the inescapable limits of the Self, and showing it will be our central argument. 
In order to understand the transition 'from paint to pixel', we need to create a historical framework that led to it, especially in relation to the philosophical ideas which have at their core the aesthetic experience of the Sublime, from Jean Francois Lyotard influential essays for Artforum "Presenting the Unpresentable: The Sublime", 1982, and "The Sublime and the Avant Garde", 1984, together with "Les Immateriaux" exhibition in the Centre George Pompidou in 1985, up until Jeremy Gilbert-Rolfe Post-Human Techno Sublime in the volume "Beauty and the Contemporary Sublime", 1999. In this main body of the paper, we will answer the questions raised during the methodology and will analyze the data we found, in relation to specific artworks that cover in a characteristic manner the spectrum of digital art in Greece and their expression of the New Sublime [3].

\section{Main Body \\ 3.1. Theoretical analyses}

Nowadays, according to Simon Morley, the incredible power of technology is more likely to supply the raw material for what can be termed a characteristically contemporary sublime [4]. The extreme space-time compressions produced by globalized communication technologies give rise to a perception of the everyday as fundamentally destabilizing and excessive. This is further enhanced by the quick interchanges, in the newsreel and the social media, between the awe-inspiring and banal, the unbelievable and the ordinary, the horrific and the beautiful, the virtual and the real [5].

In 1985 Jean Francois Lyotard curated "Les Immatériaux" at the Centre Pompidou in Paris, and brought for the first time these ideas to a wider public. The globalized 'sensus communis' [6] caused by the Sublime gives its place in a personal experience, an 'empirical event' that occupies the senses and which takes place within the work of art itself. Uncertainty about what exactly is happening is absolutely important because it protects the experience of the Sublime from creating an explanation or a thematic-concept that 'encloses' the event within an explainable one, a framework that deprives it of multiple possibilities for mutation.

For Lyotard, contemporary art 'dematerializes' art, in a political act that presents what would not be presented according to axioms, contracts, the commonplace, all necessary for the flow of a unified society of mass consumption [7]. In this way Lyotard gives a new political dimension in Sublime that denies the consensus of a unanimous ruling party. The value of the experience it submits sensually and mentally to the viewer, functions as a dialogue-discourse, or as a philosophical essay whose words are replaced by objects and documents, enhancing the role of the curator as the 'author' of the report. This quality armed him to create an emotional dramatic set of information of art works, along with words, sounds, signals and symbols in an effort to address the future of a world that suddenly began to change faster than ever.

The avant-garde of this report was also based on a non-linear, labyrinthine structure based on the breaking of the narrative and its montage of the images by the viewers [8], as there was complete freedom in their choice browsing the exhibition, as well as its interactive nature through dioramas, chess games, early video projections. In this exhibition the Sublime unfolded in front of the viewers' eyes as an open-ended, multisensory set of questions defying any notion of set values, portraying the multiple versions of man's awesomely unglorified unanswered questions about the sublimity of his own being, that became the favorite subject matter in the art of contemporary Sublime [9].

While Jean-Francois Lyotard became the forerunner of an art that defies spatial borders, as well as opening up the ideological confinements of the white cube of the museum/gallery space, aspects ingrained in the scopes and development of digital art, Jeremy Gilbert-Rolfe, 
in the advent of the new century, reformulates the conceptions of awe and sublimity in the post-human era, searching for its new expressions in technology. In a meta-Metropolis epoch, humans stop producing and become consumers that serve the machines that produce [10]. Human knowledge is still necessary but human beings are redundant.

The kind of art that represents the automation of personality find its expression through digitally generated images. The machine might not yet be capable of free thinking, but it can calculate, store, record and transmit artistic creation on a massive scale. It's limitlessness and power to convey or even transform the mystery without seemingly using a lot of effort, is a Sublime act in itself. It records without relying on human memory, it transmits without spoken words. It is more unbounded than the vastness of Friedrich's landscapes, and conquers over space and time.

\subsection{Case Studies}

The motherland of classical art, Greece, an Et in Arcadia Ego point of reference for $19^{\text {th }}$ century Romantic Grand Tourists, two centuries later seems to transform itself to an experimental, fertile field of artistic research into the New Sublime as it is expressed by a younger generation of artists seeking creative channels through digital image making. Digital art centers such as Fournos-Oven Theater and Center of Digital Culture, led by the New Media Professor at the Athens School of Fine Arts Manthos Santorineos and video festivals such as Video Art Miden International Art Festival and Athens Video Art Festival establish the new digital landscape in Greece [11].

Their work focuses on experimenting with the digital image to produce works that reflect the current sociopolitical environment in the country and its relation to what is taking place across the globe, as they both invite internationally renown artists to showcase their works. At the same time the historical Athens School of Fine Arts ${ }^{10}$ recently established the first Postgraduate Study Program "DIGITAL ARTS". Object of the course is the specialization, research and experimentation in the field of modern visual practices, through the use of timebased media, interactive, computational, in combination with the systematic theoretical training of students in a range of fields and objects which concern mainly the historical and philosophical-aesthetic study, of the technical means (photography, cinema, videography, digital computer systems) and of the cultural technologies.

The recent pandemic brought about a new influx of art works aiming to digitally express the unnatural situation humanity found itself into, a mixture of alienation and virtual proximity. Art fairs and museum shows took place on-line such as Platforms Project [12], where there are some artistic collectives/art platforms dealing with the subject of the aweinspiring post-human element in contemporary art, such as Cyborg/Asma [13].

In order to explore the most representational artistic voices of the digital milieu focusing on a new take on the Romantic Sublime, is helpful to attempt a thematic categorization according to subject matter.

\subsubsection{Cyberbodies}

The nightmarish digital utopias by Theo Triantafyllidis have granted him a place in the international art scene. His videos overflow with stylized theatricality of a collectively formed fantasy of the world the Day After. The world has subsided and the survival is not only a business of the fittest but also the ones that carry with them the flaws of the past. The new reality is spectacularly toxic, while his anti-heroes, like avatars from video games, they perform their actions of salvation and renewed artistic creation, with such attentiveness so 
that the spectators remain oblivious of the actual space, time and adherence to a bizarre new reality or a dream gone wrong (fig.1) [14].

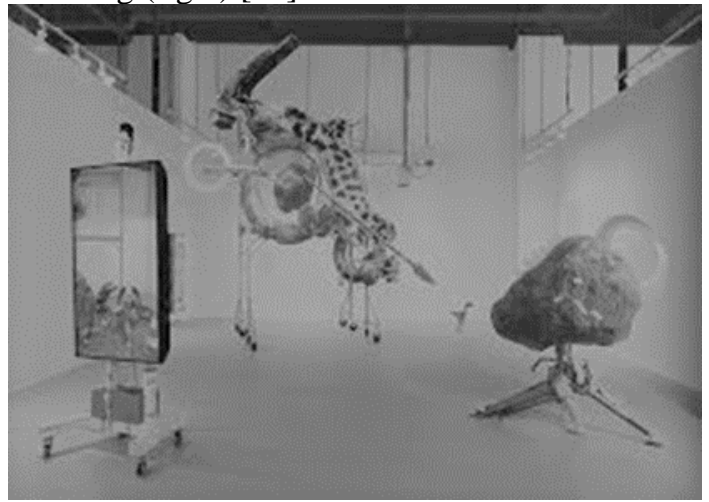

Fig.1 Theo Triantafyllidis, Studio Visit, 2018

George Oiback is a painter of oil paintings, grand in scale, borrowing from graffiti and comic book iconography. Recently he steered towards video animation, where he employs his painterly technique in order to express, with sardonic humor, his bewilderment around the games of political power that affect both the aesthetic landscape and the ethical values of humanism. Creating a world roamed by anti-heroes full of chemical testosterone and fake super-powers, the artist immerses himself into a technicolor yet noir atmosphere of a selfmade Nouveau Nihilism where the image becomes the fact and reflects a perverse reality. The ways his technique adopts the quality of analogue early cartoon making in presenting apocalyptic scenes, plays along with the ambiguousness of where does the truth lies within the work itself (fig.2) [15].

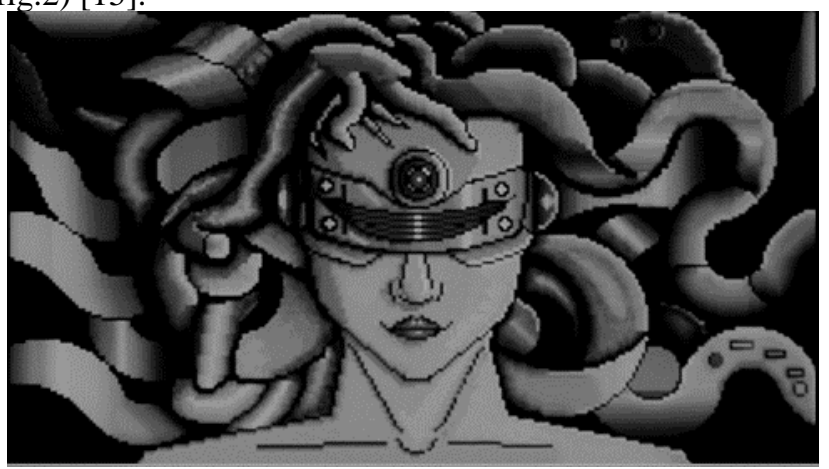

Fig.2 George Oiback, Medusa Overload, 2020

\subsection{Ecological Sublime}

A fellow painter turned video artist is Sotiris Batzianas ${ }^{15}$ who paints elaborate magical realism canvases with subject matter taken from dreams and childhood experiences. Then he picks several of his fantastic painted Borgean beings and creates animated surrealist narrations. The 'play' is a means of imitating reality (mimesis) and re-living familiar and uncanny experiences, creating a potential space, somewhere in-between reality and imagination, where he orchestrates compositions about eroticism, violence, a play of the sacred and the profane. Like a child at play, he criticizes the actions of the adult world and 
places his stories against a post climate crisis natural background foraged by destruction and bizarre mutations than reminds the Chapman Brothers [11].

Always fascinated by the complex storytelling of Hieronymus Bosch, Pieter Bruegel and Eastern Miniature painting, Batzianas creates multiple collateral stories that add postnarrations in his main work's narrative. The results are fragmented, without linear narrative, according to Lyotard dissolution of a clear didactic scope or message (fig.3).

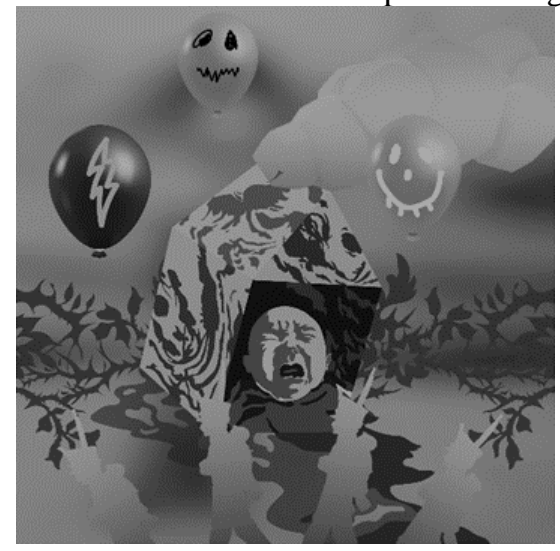

Fig.3 Sotiris Batzianas, Phalaenopsis, 2021

Gioula Papadopoulou is one of the most prominent video artists in Greece that often traces the Sublime in idealized settings. In her most lyrical work "When I Was the Moon", Papadopoulou addresses a celestial object as if it were a human being and follows its journey along mountain tops, foliage, tree canopies, caves and eventually a primordial sea, where it dives to be lost forever. The way the artist personifies and digitally manipulates nature, brings the viewer closer to the physical ways of nature, where harmony prevails and entropy reignites our interest in the Natural Sublime (fig.4) [11].

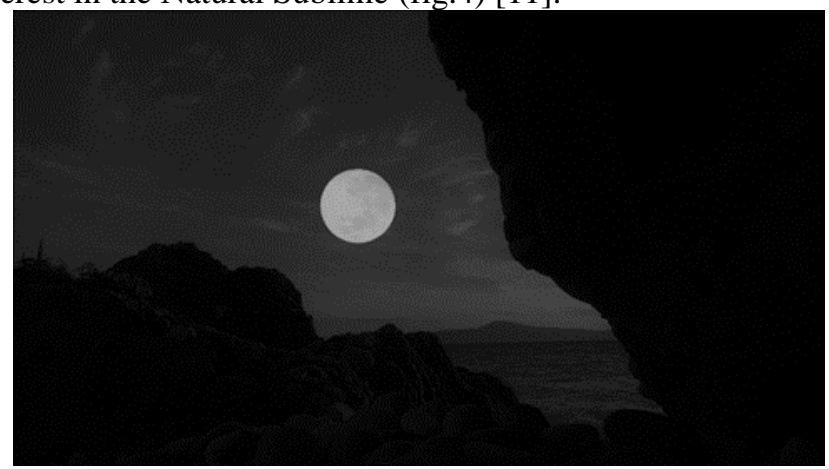

Fig.4 Gioula Papadopoulou, When I was the Moon, 2020

Kyriaki Goni is a multimedia artist who creates elegiac projections and video works on the sounds and biomorphic shapes of nature that is slowly losing its autonomy and viability. In the video work "The Portal, or Let's Stand Still for the Whales", she combines a technological, abstract matrix of a city industrialized grid where everything is fragmented and all communicate via computers, but is rehumanized and re-naturalizes, as it is engulfed by narration, and permeated with natural whale sounds. The intrusion of nature in the seemingly safe enclosure of the city, creates an atmosphere of awe and anticipation for something that seems about to happen, as nature seemingly prepares for its final battle [16]. 


\subsubsection{History vs Myth}

Phoebe Giannisi, a Poet, Professor of Architecture and co-curator of the Greek Pavillion of the $12^{\text {th }}$ Venice Biennale of Architecture, is a multidisciplinary artist that engages language, performance and film to create a path towards a mythical, primeval past, as the birthplace of the Sublime. Her "Thetis and Chimera" video consists of adopting the ancient myth of the Goddess of the sea who was going to bear a child-hero, Achilles, a half-immortal tragic figure. Thetis becomes a symbol of female power, a gender icon of all female characteristics of a watery image in constant flux and of a flowing poetic language. Presenting the images of the Squid and the Goat, both animals indigenous to Greece, the artist looks back to the zoomorphic as well as to the female earth goddesses, long before patriarchical models of social hierarchy come into power. The Sublime for Giannisi has female form, is voluptuous and luxurious like nature in Spring [17].

Marina Gioti, in her videos, she is interested in collecting archival material such as an old $8 \mathrm{~mm}$ dramatized documentary on the urban myth of "Secret School", referring to the clandestine schooling by the Orthodox Church when Greece was under the Ottoman rule, just before the 1821 War of Independence. The documentary is focused on the portrayal of the Secret School in the famous $19^{\text {th }}$ century homonymous painting by Nikolaos Gyzis 1885 . The painting becomes the center of a narrative by a family that visits the museum where it hangs so as to marvel its heroical connotations as it comes to life, during the Greek military junta of 1967-1973. The militaristic government of the Junta, sharing a common tradition among every totalitarian regime around the world, was in favor of creating visual propaganda narratives of great ideas oncerning the creation of a nation based on strong beliefs of power and dominance over the rest of the neighboring states. Under this light, the video is a helpful manual on how to construct sublimity that would serve as a heroic medium for a suppressive political status quo, in contrast to the writings of Lyotard and his disrespect of creating art with a mission (fig.5)[18].
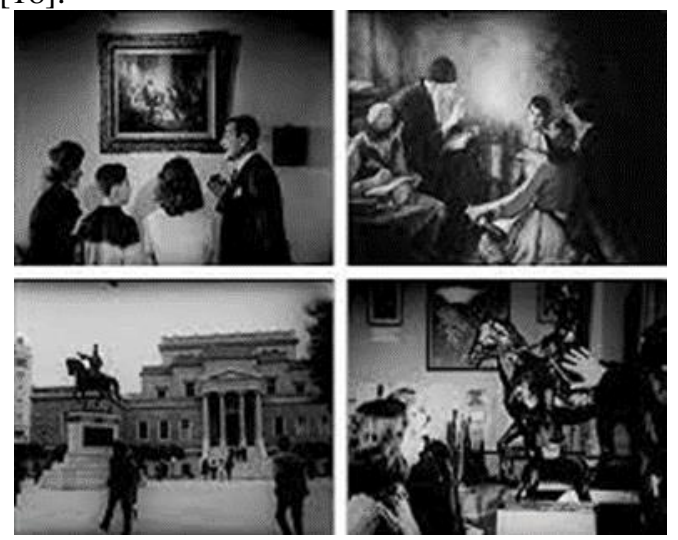

Fig.5 Marina Gioti, Secret School, 2009

Alexandros Psychoulis, Professor of Fine Arts in the University of Thessaly, in his video "Alexandros Delmouzos and the 80 May Beetles" presented in Documenta 14, delves too into history to narrate a story on how freedom was being misunderstood in the educational system of the early $20^{\text {th }}$ century. Delmouzos was a visionary pedagogue who believed that an everyday contact with the sublimity of nature and life is even more important than a sterile education based mainly on books. He created the first female school of Volos but it was shortlived, as there was pressure against the innovative ways of learning- that prompted a witchhunt- that included tree-hugging and performing CPR. Psychoulis creates a digital 
rendering of flowing, lyrical images of young girls engaging in repetitive, ceremonial actions within natural surroundings, such as lifting their skirts to allow free movement, or dragging one-another by pulling each-others ponytails with their teeth, to suggest the so called 'hairy' language that they used at school, namely a colloquial form of spoken Greek jargon, away from the verbal decorum of the era (fig.6) [19].

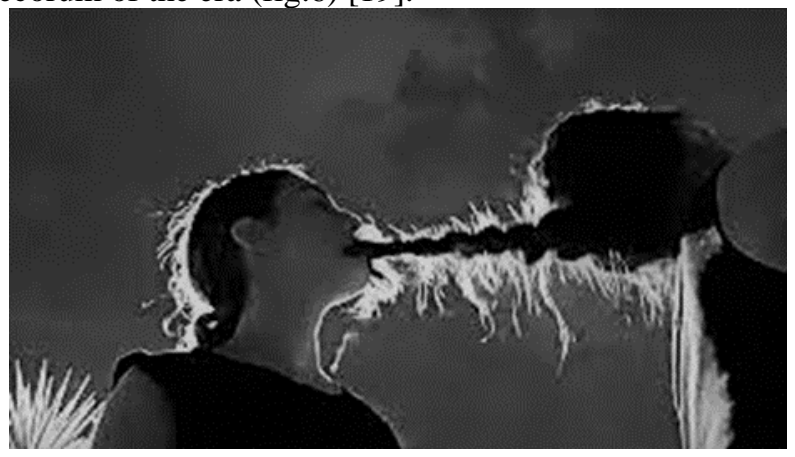

Fig.6 Alexandros Psychoulis, Alexandros Delmouzos, 2014

George Drivas, the Greek representative artist for the 57th Venice Biennale with the seminal work "Laboratory of Dilemmas", 2017 with the seminal work takes on the Greek tragedy Iketides-Pleading Women by Aeschylus to comment on the chasm between locality and the introduction of a foreign population in a very timely parabole of a virus attack. The sleek architectural, biological and mythological story evolves around the ancient story of women seeking asylum, so timely in our era of moving populations, whose pleas are debated and then acted out with an array of outcomes. At the same time, a parallel story is being unfolded, a fictional documentary of a biological drama about a medical experiment, to create virus-resistant cells which goes horribly wrong as new sells unite with the host cells to create a new cell colony. The decision in this Kantian argument between a group of 'experts', including in the cast the famous actress Charlotte Rampling, is whether to kill the new cells or allow them to grow and expand. Again, the immaterial threat of an external factor recalls both Lyotard and Jeremy Gilbert Rolfe and the latter's warnings on our responses to a possible uncontrollable nature of the Technological Sublime (fig.7) [20].

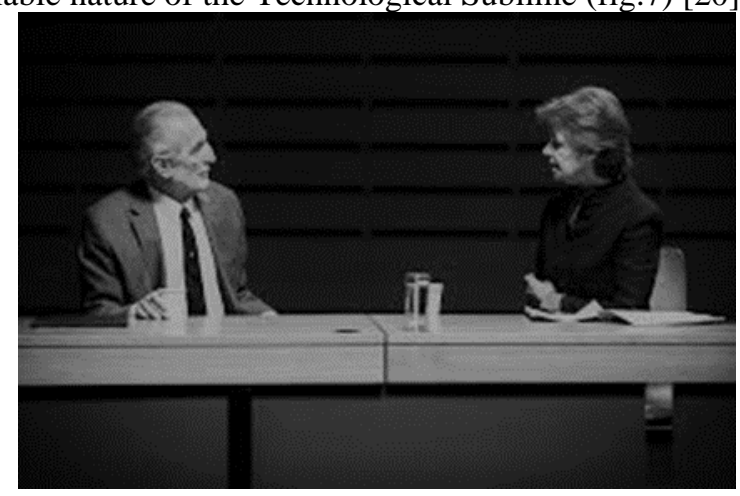

Fig.7 George Drivas, Laboratory of Dilemmas, 2017

The same artist, in the summer of 2020, in the midst of the pandemic, presented his solo show "Structures of Feelings" at the Megaron in Athens. Once again, within a very stylized environment, possibly the offices of a multinational, a single human being is seeking one's 
own identity during times of transience, like an archetypal Romantic hero standing on the verge of his personal abyss, staring into the New Sublime of faceless individuals and cold surroundings.

\subsubsection{City Confinements and The Fearsome Everyday}

The acclaimed young Greek director and video artist Vassilis Kekatos created a utterly poetic video work during the Pandemic, "As You Sleep the World Empties", a visual elegy of a montage of images taken during the quarantine, of empty abandoned spaces and fragmented memories of life before, that were aimed to be narrated, like readings of postcards, for a loved one who slept through it [21].

\subsubsection{The Future Present}

The digital new new-age interactive environments by Angelo Plessas, is an ultra-new age of digitally manipulated work combined with pseudo-eastern religions' elements that offer relaxation and self- actualization. The practices of the Noospheric society, which is part of the 13th Gwangju Biennale 2021, consist of sounds, algorithms, magical elements such as mandalas and chants as well as actual physical presence in performances that Plessas as a digital shaman organizes around the world to evoke synaesthesia. The physical and the digital merge to aid the discovery of the Sublime within the mind. (fig.8) [22].

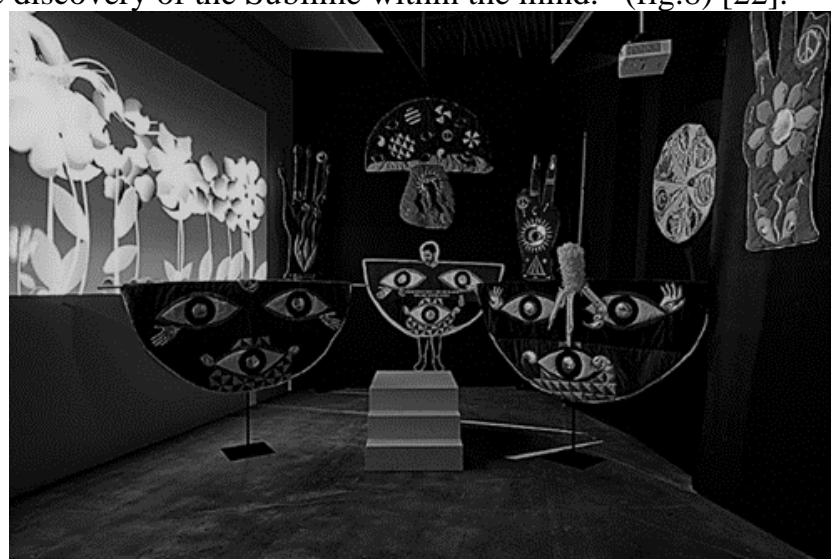

Fig.8 Angelo Plessas, The Noospheric Society, 2021

Overall, the 'digitization by necessity' is taking place right this moment in the art world, in the times of the COVID19 pandemic, when the artists are forced to be visible in a virtual way, and when most of the art shows and fairs take place in cyberspace. This could be a turning point for art, seeking to express itself in various novel and more accessible to the public ways rather than inside the typical 'white cube' enclosed environment of the gallery or the museum. Possibilities include art opening to a wider audience and becoming more interactive, with the aid of technology, as well as new and promising opportunities for displaying public art such as open art studios that begin to emerge across the globe, and further possibilities of participating in and define the variety of art being produced and presented. 


\section{Results}

After the thorough examination of the history and presence of Greek digital art up to this date, we come to a conclusion that there is what we call a fully blown digital art scene in Greece, the country at the Southeastern corner of Europe, known for its ancient, classical art tradition. Our review included the most characteristic works by the contemporary artists chosen as the examples of art working hand in hand with technology, in order to discover the myths hidden in the everyday, is an endeavor to show that the future of art, in its large part, inexorably depends upon the power of the digital image and its multifarious and multifaceted expressions of the Contemporary Sublime. Since our lives gradually get more digitized, art will use technology as a tool for more creative and novel ways of expressing the world, in and out of the screen.

\section{Acknowledgments}

This research is co-financed by Greece and the European Union (European Social FundESF) through the Operational Programme «Human Resources Development, Education and Lifelong Learning 2014-2020» in the context of the project "Contemporary Art and New Media: Digitality, Interaction and the Internet. Greek artists - creators, works of art, exhibitions and their reception by the public "." (MIS5047907 -ID :46278(2019/1))."

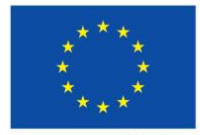

European Union European Social Fund
Operational Programme Human Resources Development, Education and Lifelong Learning

\section{References}

[1] Grau, O., \& Veigl, T. (2011). "Introduction: Imagery in the 21st Century”. In O. Grau \& T. Veigl, Imagery in the 21st Century (pp. 1-18). London: The MIT Press.

[2] Lyotard, J. (1991). The Sublime and the Avant-Garde. Cambridge: Polity Press.

[3] Longinus. (1995). On the Sublime. Mass: Harvard University Press.

[4] Morley, S. (2010) (ed.). The Sublime. Documents on Contemporary Art. London: Whitechapel Gallery, 12.

[5] Morley, S. (2010). The Sublime: Documents of Contemporary Art. London:

Whitechapel Art Gallery/ The MIT Press, Cambridge, Mass.

[6] Benjamin, A. (1992) (ed.). Judging Lyotard. London: Routledge.

[7] Lyotard, J. (1994). Lessons on the Analytic of the Sublime. California: Stanford

University Press.

[8] Deleuze, G. (1995). 'Mediators' in Negotiations 1972-1990. New York.

[9] Lyotard, J. (1982). Presenting the Unpresentable: The Sublime. New York: Artforum.

[10] Gilbert-Rolfe, J. (1999). Beauty and the Contemporary Sublime. New York: School of Visual Arts.

[11] Hatziyiannaki, A. (2012). New Media art in Greece. Goethe-Institut, 1-18.

[12] Platforms Project 2021 Independent Art Fair Online Platforms Project NET. (2021).

Retrieved 29 April 2021, from https://platformsproject.com/

[13] CYBORG/ASMA. (2021). Retrieved 29 April 2021, from

https://platformsproject.com/platforms-2021-teaser/platform/cyborg-asma/ 
[14] Onassis Foundation. (2021). Retrieved 29 April 2021, from https://www.onassis.org/el/video/anti-gone-theo-triantafyllidis [15] George Oiback - Robot - George Oiback. (2021). Retrieved 29 April 2021, from https://artsandculture.google.com/asset/george-oiback-\%E2\%80\%93-robot-georgeoiback/GgHW_yD1RgIYag?hl=en [16] National Museum of Contemporary Art. (2020). Theorimata. On History (26/91/11/2020). Exhibition Catalogue. Athens.

[17] Phoebe Giannisi. (2021). Retrieved 29 April 2021, from http://phoebegiannisi.net/en/proj.php?id=22

[18] Marina Gioti. (2021). Retrieved 29 April 2021, from https://www.documenta14.de/en/artists/13549/marina-gioti [19] Alexandros Psychoulis. (2021). Retrieved 29 April 2021, from https://www.documenta14.de/en/artists/22292/alexandros-psychoulis [20] Laboratory of Dilemmas - Greek Pavilion at the Venice Biennale. (2021). Retrieved 29 April 2021, from http://laboratoryofdilemmas.gr/

[21] Onassis Foundation. (2021). Retrieved 29 April 2021, from https://www.onassis.org/people/vasilis-kekatos [22] The Noospheric Society, Angelo Plessas, 2021. (2021). Retrieved 29 April 2021, from http://noosphericsociety.com/\#/ 